2

I N S A N

\title{
Pengaruh Edukasi Kesehatan Mental Intensif Terhadap Stigma pada Pengguna Layanan Kesehatan Mental
}

\section{JONATHAN SOEBIANTORO ${ }^{1}$}

1 University of Melbourne, Australia

\begin{abstract}
ABSTRAK
Stigma terhadap pengguna kesehatan mental adalah masalah yang serius di Indonesia karena tingginya angka prevalensi masalah kesehatan mental. Kami memiliki hipotesis bahwa membaca artikel psikoedukasi secara intensif mampu menurunkan stigma sosial dan pribadi yang disematkan pada pengguna layanan kesehatan mental secara signifikan. Studi ini adalah studi kuantitatif dengan metode eksperimen melibatkan 20 partisipan (Pria $=10$, Wanita $=10)$ dengan peserta paling muda berusia 19 tahun dan paling tua 52 tahun $(M=31.00, S D=9.038)$ yang dialokasikan secara acak dalam 2 grup eksperimen (kontrol dan intervensi). Studi ini menemukan bahwa stigma sosial dapat dikurangi secara signifikan dengan membaca artikel psikoedukasi studi ini secara intensif (Mann-Whitney $U=24.5, n_{1}$ $=n_{2}=10, p<.05$, two tails). Studi kami memiliki potensi untuk mendukung program Indonesia bebas pasung dengan meneliti cara - cara mengurangi stigma pada penderita gangguan jiwa dan layanannya.
\end{abstract}

Kata kunci: edukasi, layanan kesehatan mental, stigma

\begin{abstract}
Stigma toward the users of mental healthcare service in Indonesia is a significant problem, which is apparent in the mental health problem's prevalence level. We hypothesized that: by reading psychoeducation article intensively, participants will have significant reduction in their social and selfstigma level toward mental health service and its users. This is a quantitative study with experimental methods, which involved 20 participants $(M a l e=10$, Female $=10)$ with the youngest participant aged 19 and oldest aged $52(M=31.00, S D=9.038)$; allocated randomly into 2 experimental groups (control and intervention). This study finds that the level of social stigma could be reduced significantly by reading the study's psychoeducation article intensively (Mann-Whitney $U=24.5, n_{1}=n_{2}=10, p<.05$, two tails). This study could potentially support the Indonesian's Ministry of Health program to reduce the deprivation and restraining of rights applied to the mental health service users in the society.
\end{abstract}

Key words: education, mental healthcare service, stigma 
INSAN Jurnal Psikologi dan Kesehatan Mental, 2017, Vol. 2(1), 1-21, doi: 10.20473/jpkm.v2i12017.1-21

Dikirimkan: 27 November 2016 Diterima: 31 Mei 2017 Diterbitkan: 26 Juni 2017

Editor: Rizqy Amelia Zein

*Alamat korespondensi: Jalan Kertajaya Indah Timur XVII/55, Surabaya, Jawa Timur 60117. Surel: jsoebiantoro@y7mail.com

Naskah ini merupakan naskah dengan akses terbuka dibawah ketentuan the Creative Common Attribution License (http://creativecommons.org/licenses/by/4.0), sehingga penggunaan, distribusi, reproduksi dalam media apapun atas artikel ini tidak dibatasi, selama sumber aslinya disitir dengan baik.

\section{PEN D A H U L U A N}

Masalah gangguan mental di Indonesia masih sangat tinggi prevalensinya, terutama pada kalangan usia lima belas tahun keatas. Menurut data Riset Kesehatan Dasar (Riskesdas) Kementerian Kesehatan Republik Indonesia, tingkat kecenderungan kasus gangguan kesehatan mental (emosional) yang ditunjukkan melalui gejala seperti depresi dan panik/kecemasan adalah sebanyak 6\% pada kalangan 15 tahun keatas (sekitar empat belas juta orang). Jika melihat kasus gangguan schizophrenia terdapat prevalensi sebanyak 1.7 tiap 1000 penduduk atau sekitar 400000 orang (Badan Penelitian dan Pengembangan Kesehatan, 2014). Dengan melihat kondisi demikian, sudah saatnya penggunaan layanan kesehatan mental dibuat maksimal dengan cara meningkatkan kesadaran masyarakat akan gangguan kesehatan mental.

Namun, pada kenyataannya penggunaan layanan kesehatan mental secara maksimal masih terhalang dengan adanya stigma kepada penderita gangguan mental yang datang baik dari individu itu sendiri maupun lingkungan sosial. Manifestasi stigma tersebut terjadi ketika penderita gangguan kesehatan mental dipasung (dihalangi kebebasannya) dengan cara diisolasi dari masyarakat sekitar karena rasa malu keluarga. Salah satu ciri-ciri stigma dari lingkungan keluarga adalah rasa malu jika anggotanya yang terkena gangguan mental terlihat masyarakat sekitar. Stigma adalah persepsi negatif yang dikenakan oleh masyarakat dan individu penderita itu sendiri pada penderita gangguan jiwa.

Stigma memang memiliki dua komponen, yaitu stigma dari publik/sosial dan stigma dari individu/pribadi itu sendiri (Goffman, 1963; Lestari \& Wardhani, 2014). Stigma dari publik atau lingkungan sosial adalah pandangan dan reaksi negatif yang disematkan lingkungan/masyarakat pada penderita gangguan jiwa. Misalnya, penderita gangguan mental itu tidak bisa diterima dalam kehidupan bermasyarakat (Corrigan, 2004; Hobson, 2008). Sedangkan, stigma individu atau pribadi adalah stigma masyarakat yang diterima dan dimengerti oleh individu penderita yang bisa berakibat pada menurunnya rasa percaya diri dan harga diri (self-esteem \& self-worth) (Corrigan, 2004; Hobson, 2008). Misalnya, individu penderita merasa karena dirinya memiliki gangguan mental, dia adalah seorang yang tidak berguna.

Di Indonesia, besarnya stigma yang dilabelkan oleh masyarakat terhadap penderita gangguan jiwa masih sangat kuat, sehingga penderita merasa terkucilkan (Suryani, 2013). Selain itu, usaha untuk menurunkan stigma terhadap penderita gangguan jiwa adalah penting, karena golongan profesional dan intelektual juga bisa memiliki stigma tersebut terhadap penderita gangguan jiwa (Keane, 1990; Lyons \& Ziviani, 1995; Mirabi, Weinman, Magnetti, \& Keppler, 1985; Page, 1980; Scott \& Philip, 1985; Corrigan, 2000). Maka dari itu, stigma lingkungan/masyarakat yang kuat membuat stigma yang dilabelkan individu penderita terhadap dirinya sendiri menjadi sangat kuat. Stigma yang dilabelkan oleh penderita sendiri membuat individu/penderita menolak diagnosa gangguan jiwa dan pada akhirnya membuat individu/penderita menolak pengobatan.

INSAN Jurnal Psikologi dan Kesehatan Mental

2017, Vol. 2(1), 1-21

doi: 10.20473/jpkm.v2i12017.1-21 
Terlebih lagi, karena adanya stigma yang kuat, "keluarga akan menolak apabila ada anggota keluarga yang dideteksi memiliki gejala gangguan jiwa", ini dapat mengakibatkan keterlambatan penanganan penderita (Lestari \& Wardhani, 2014, hal. 162). Dari hal demikian, dapat ditemukan adanya hubungan antara stigma dari lingkungan dan individu terhadap intensi untuk mencari pengobatan atas gangguan jiwa. Yakni, jika stigma dapat diturunkan maka kemungkinan intensi untuk mencari dan menggunakan layanan kesehatan mental bagi penderita kesehatan jiwa dapat ditingkatkan. Dalam konteks yang sama, Hobson (2008) menekankan bahwa dengan mengedukasi publik mengenai kesehatan mental dan apakah kegunaan layanan kesehatan mental itu, selain menurunkan stigma, juga dapat meningkatkan kesediaan individu untuk mencari dan menggunakan layanan kesehatan mental.

Kami merujuk kepada Zajonc (1968) untuk mencari cara meningkatkan konsep positif anggota masyarakat terhadap konsep kesehatan mental melalui perubahan kecenderungan/sikap dengan cara melakukan pemaparan secara intensif terhadap konsep kesehatan mental. Misalnya, penghadapan semata (mere exposure) dapat mengubah kecenderungan seseorang terhadap sesuatu hal ketika dilakukan cukup sering. Contohnya, dalam studi yang dilakukan oleh Zajonc (1968, hal. 13) ditemukan bahwa ada tren antara frekuensi pemaparan seseorang dengan sebuah kata sifat dengan favorability rating akan kata-kata sifat itu. Dalam studi ini, eksperimenter menunjukkan dan melatih pengucapan kata - kata sifat dalam Bahasa Turki yang dimana partisipan tidak mengetahui artinya. Frekuensi yang dinyatakan dalam range lebih tinggi dalam studi ini adalah 5, 10, dan 25 kali; lebih rendah adalah 0, 1, dan 2 kali. Eksperimenter dengan konsisten menemukan bahwa subjek penelitian menilai bahwa katakata sifat yang tidak diketahui tersebut diartikan baik ketika mereka telah ditunjukkan kata-katanya oleh eksperimenter dan mengucapkannya lebih sering. Lebih lanjut, memang dalam studi itu, beberapa kata memang dinilai lebih baik oleh subyek dari kata lainnya dan efek signifikansinya tinggi $(F=8.35$; $\mathrm{df}=11 / 781 ; \mathrm{p}<.001$ ). Dengan demikian, menurut literatur tersebut, jika kami memaparkan partisipan studi kami kepada konsep positif mengenai kesehatan mental melalui bacaan edukasi kesehatan mental cukup sering, maka kecenderungan partisipan terhadap kesehatan mental dapat menjadi lebih baik (attitude enhancement) (Zajonc, 1968, hal. 21, 23).

Dengan kecenderungan yang berubah lebih baik, kami juga mengharapkan penurunan pada level stigma individu dan sosial terhadap pelayanan kesehatan mental dan penggunanya. Pemaparan secara berulang-ulang mungkin membuat ketersediaan informasi bertambah dalam pikiran individu sehingga seorang individu merasa suatu stimulus itu familiar dan tidak berbahaya. Misalnya, jika sebuah stimulus itu jika dikaitkan dengan hal-hal di lingkungan secara berulang-ulang tidak menimbulkan sesuatu hal yang membahayakan keselamatan dirinya, maka stimulus itu dianggap tidak berbahaya.

Dari sisi atribusi sosial, menurut Corrigan (2000), teori atribusi sosial memang dapat menjadi dasar yang luas untuk menjelaskan stigma pada penderita gangguan jiwa. Ini dikarenakan atribusi sosial memberikan kita cara untuk menilai perilaku orang dalam kehidupan kita (Eysenck, 2009, hal. 414). Riset pada atribusi sosial menemukan dua atribusi sosial paling penting untuk penderita gangguan jiwa; atribusi stabilitas dan kontrolabilitas (Weiner, 1993, 1995; Corrigan, 2000). Atribusi stabilitas menyatakan bahwa penderita gangguan jiwa tidak bisa disembuhkan/tetap seperti itu sepanjang hidupnya. Sedangkan, atribusi kontrolabilitas adalah penderita gangguan jiwa itu pantas dianggap bersalah karena kondisi jiwanya. Artikel edukasi kesehatan mental kami secara gamblang menantang atribusi ini dengan menyelipkan pesan bahwa tidak ada yang perlu dipersalahkan dalam masalah gangguan jiwa. Namun, Corrigan, dkk. (2001) menemukan bahwa edukasi tidak dapat mengurangi atribusi kontrolabilitas stigma terhadap penderita gangguan jiwa secara signifikan. Ini dikarenakan efek edukasi yang lebih signifikan jika digunakan memerangi atribusi stabilitas gangguan jiwa (Corrigan, dkk., 2001). Temuan ini agak mengecewakan karena penolakan dari masyarakat dan sikap keluarga terhadap penderita lebih berhubungan dengan atribusi kontrolabilitas (Weisman, dkk. 1993; Crandall \& Moriarty 1995; Hooley \& Licht 1997; Corrigan, dkk., 2001).

INSAN Jurnal Psikologi dan Kesehatan Mental

2017, Vol. 2(1), 1-21

doi: 10.20473/jpkm.v2i12017.1-21

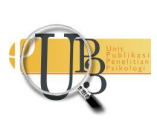


Temuan Corrigan, dkk. (2001) terhadap pengaruh edukasi terhadap atribusi stabilitas dapat dipahami. Mungkin setelah mendengar edukasi kesehatan mental, seseorang dapat lebih mengetahui situasi si penderita gangguan jiwa. Maka, dengan merujuk kepada atribusi situasional, ketika seseorang merasa bahwa si penderita gangguan mental memiliki situasi yang membuatnya bertindak seperti itu dan ada kecenderungan berempati. Jadi, orang tersebut dapat dengan lebih bersedia mengadopsi atribusi stabilitas yang positif. Misalnya, layanan kesehatan mental dapat memberikan efek yang positif bagi si penderita dengan cara membantu pemecahan masalah hidup si penderita dan membuat si penderita lebih mungkin sembuh (Corrigan, dkk., 2001).

Namun, kontak dengan penderita gangguan jiwa (secara tidak langsung) dapat menurunkan pandangan stigma peserta secara signifikan (Corrigan, dkk., 2001, hal. 191-92). Dalam kontak sosial, orang lain dapat menerima lebih banyak informasi mengenai kehidupan si penderita gangguan jiwa, sehingga dapat memberi atribusi yang lebih tepat (Corrigan, dkk., 2001, hal. 193). Ini dikarenakan pemaparan secara sosial ke grup lainnya yang dipersepsikan negatif dapat memperbaiki kecenderungan terhadap grup itu. Misalnya, dengan melakukan pemaparan tersebut, kita akan belajar belajar cara pandang (perspective taking) grup itu dengan dibantu (mediasi) oleh empati dan atribusi sosial; akhirnya mengubah sikap kita terhadap grup itu menjadi lebih baik (Vescio, Sechrist, \& Paolucci, 2003). Sedangkan edukasi kesehatan mental dapat mengubah pandangan seseorang mengenai layanan kesehatan mental. Yakni, edukasi kesehatan mental dapat meyakinkan orang di sekitar penderita bahwa layanan kesehatan mental seperti konseling dapat memberi efek yang menguntungkan untuk penderita (atribusi stabilitas) (Corrigan, dkk., 2001, hal. 193).

Selain itu, hubungan yang lebih kuat antara penolakan dari masyarakat dan atribusi kontrolabilitas juga beralasan secara teoritis. Misalnya, banyak riset telah menunjukkan kondisi cacat mental dan jiwa lebih cenderung diatribusikan masyarakat sebagai kondisi yang secara pribadi lebih dapat dikontrol daripada kondisi fisik (Corrigan, River, Ludin, Wasowski, Campion, Mathisen, Goldstein, Bergman, Gagnon, Kubiak, dalam penerbitan; Lin, 1993; Weiner, dkk., 1988, Corrigan, 2000, hal. 59). Maka, ketika masyarakat menemukan kondisi gangguan jiwa pada seseorang yang dianggap berbahaya dan dapat dikontrol secara pribadi, respon yang mungkin adalah kemarahan dari orang yang menilai dan pada akhirnya orang yang menilai merespon dengan reaksi punitif (Corrigan, 2000, hal. 58). Reaksi punitif ini bertujuan untuk menjaga konformasi sosial di masyarakat yang dapat juga melalui aksi penanganan terhadap gangguan jiwa secara psikologis (Corrigan, 2000, hal. 58). Namun, kebanyakan orang lebih bereaksi terhadap ancaman bahaya dengan ketakutan (Johnson-Dalzine, Dalzine, \& Martin-Stanley, 1996; Corrigan, 2000). Dengan ketakutan itulah, masyarakat lebih cenderung menolak dan menjauhi orang yang terkena gangguan jiwa daripada menolong.

Sebelumnya, Hobson (2008) telah meneliti efek edukasi kesehatan mental terhadap stigma individu, publik dan intensi seseorang untuk menggunakan layanan kesehatan mental. Studi Hobson menggunakan 196 orang sebagai sampel (Pria=99 orang, Wanita=97 orang). Rata-rata umur adalah 24.55 tahun (kisaran usia=18-54 tahun, $\mathrm{SD}=5.95$ ). Studi ini merekrut partisipan dengan menggunakan convenience sampling, karena sifat partisipasi bersifat sukarela. Partisipan kemudian didistribusikan ke grup intervensi dan kontrol secara acak dengan mengacak paket survei yang ada.

Studi Hobson (2008) menyelidiki pengaruh edukasi kesehatan mental terhadap stigma pribadi dan sosial terhadap pengguna layanan kesehatan mental dengan desain studi eksperimen dan antara subyek (between-subjects), dengan memisahkan subyek grup eksperimen dan kontrol. Para partisipan grup eksperimen diminta membaca artikel edukasi kesehatan mental terlebih dulu dalam bacaan tanya jawab dan mengisi empat bagian survei. Dalam kondisi kontrol, partisipan hanya mengisi empat survei tersebut. Studi Hobson (2008) menemukan bahwa edukasi kesehatan mental secara singkat dapat secara efektif menurunkan stigma pribadi dan sosial pengguna layanan kesehatan mental. 
Lebih lanjut, hasil penelitian Hobson (2008) menunjukkan bahwa edukasi kesehatan mental secara singkat dapat menurunkan stigma pribadi dan sosial secara signifikan menurut statistik. Namun, yang perlu diperhatikan disini adalah karena SD yang besar, skor rata-rata instrument-instrumen di atas untuk grup intervensi sebagian besar overlapping dengan grup kontrol (melebihi 2 standar deviasi atau 95\% data). Namun, juga perlu diperhatikan bahwa perbedaan nilai rata-rata grup intervensi untuk skala Self Stigma of Seeking Help dan Social Stigma for Receiving Psychological Help sudah lebih rendah untuk lebih dari dua standar deviasi, dan dari itulah mengapa nilai p untuk dua rerata tersebut lebih kecil dari .05. Hobson (2008) sudah melakukan tes statistika tersebut secara two-tailed untuk memberikan analisa yang lebih komprehensif dibandingkan one-tailed test. Sekali lagi, hal ini menunjukkan bahwa efek intervensi edukasi kesehatan mental signifikan secara statistik, namun jika dilihat dari overlapping data menunjukkan bahwa distribusi data kurang terkonsentrasi dan mengakibatkan data kurang bermakna secara statistik.

Namun, hal yang masih bisa dikembangkan dari studi Hobson (2008) adalah tentang intensitas edukasi kesehatan mental. Studi Hobson (2008, hal. iii, 16) hanya menggunakan edukasi kesehatan mental secara singkat (satu kali saja). Maka dari itu, studi ini kemudian menguji apakah dengan melakukan edukasi kesehatan mental secara intensif dengan menggunakan metode bacaan tanya jawab seperti studi Hobson (2008), stigma sosial dan pribadi seorang individu terhadap pengguna layanan kesehatan mental dan layanannya sendiri dapat diturunkan.

Maka dengan memperhatikan literatur yang ada (terutama dalam semangat mengembangkan studi Hobson (2008)), studi ini bertujuan untuk meneliti efek edukasi kesehatan mental secara intensif pada stigma sosial dan pribadi yang disematkan pada penderita gangguan jiwa dan layanannya. Alasan kami meneliti cara-cara menurunkan stigma terhadap penderita kesehatan mental, baik dari sisi stigma individu maupun sosial adalah karena banyak sekali individu penderita gangguan mental gagal memaksimalkan layanan kesehatan mental karena khawatir akan stigma terhadap gangguan mental dan layanan kesehatan mental (Hobson, 2008). Studi kami juga berpotensi menyelidiki apakah penghadapan semata (Zajonc, 1968) secara intensif terhadap konsep kesehatan mental mampu menurunkan stigma terhadap penderita gangguan jiwa. Menurut kami, hal ini belum diselidiki di literatur yang ada. Karena keterbatasan jumlah sampel, kami hanya meneliti dua variabel dependen yakni, stigma pribadi dan sosial.

Pertanyaan riset kami adalah: apakah membaca artikel edukasi kesehatan mental secara intensif dapat mengurangi stigma pribadi dan sosial terhadap pengguna dan layanan kesehatan mental itu sendiri? Kami memiliki hipotesis bahwa edukasi kesehatan mental secara intensif dapat mengurangi stigma sosial dan pribadi pada penderita gangguan jiwa dan layanannya.

Hipotesis Independent Groups t-test

$\mathrm{H}_{0} \quad$ : tidak ada perbedaan antara rata-rata grup intervensi dan kontrol pada variabel stigma pribadi $\left(\mu_{\mathrm{K}}=\mu_{\mathrm{I}}\right)$.

$\mathrm{H}_{0} \quad$ : tidak ada perbedaan antara rata-rata grup intervensi dan kontrol pada variabel stigma sosial $\left(\mu_{\mathrm{K}}=\mu_{\mathrm{I}}\right)$.

\section{Hipotesis Repeated Measures t-test}

$\mathrm{H}_{0} \quad$ : tidak ada perbedaan signifikan antara nilai rata-rata grup intervensi, sebelum dan sesudah intervensi secara intensif pada variabel stigma pribadi $\left(\mu_{D}=0\right)$.

$\mathrm{H}_{0} \quad$ : tidak ada perbedaan signifikan antara nilai rata-rata grup intervensi, sebelum dan sesudah intervensi secara intensif pada variabel stigma sosial $\left(\mu_{D}=0\right)$.

$\mathrm{H}_{0} \quad$ : tidak ada perbedaan signifikan antara nilai rata-rata grup kontrol, saat sesi awal dan akhir

INSAN Jurnal Psikologi dan Kesehatan Mental

2017, Vol. 2(1), 1-21

doi: 10.20473/jpkm.v2i12017.1-21

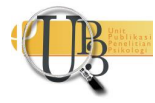


studi pada variabel stigma pribadi $\left(\mu_{D}=0\right)$.

$\mathrm{H}_{0} \quad$ : tidak ada perbedaan signifikan antara nilai rata-rata grup kontrol, saat sesi awal dan akhir studi pada variabel stigma sosial $\left(\mu_{D}=0\right)$.

Catatan: Jika perbedaan sebelum dan sesudah grup intervensi tidak jauh berbeda dari grup kontrol (dalam kasus keduanya signifikan), maka efek intervensi tidak signifikan. Namun, jika perbedaan sebelum dan sesudah grup intervensi adalah signifikan dan sebaliknya untuk kontrol, maka efek intervensi adalah signifikan.

\section{E T O D E}

\section{Partisipan}

Partisipan studi adalah 20 orang (N Pria=10, N Wanita=10) yang sudah bekerja dan memiliki penghasilan di wilayah Gerbang Kertasusila. Rerata usia untuk para peserta adalah 31 tahun (SD=9.038) dengan kisaran usia dari 19 hingga 52 tahun. Dalam grup intervensi ada 6 wanita dan 4 pria, sedangkan pada grup kontrol ada 4 wanita dan 6 pria. Dengan demikian, komposisi gender dalam studi kami dan tiap grup eksperimen hampir seimbang. Partisipan berpartisipasi secara sukarela dalam studi ini (convenience sampling) dan mereka dialokasikan secara acak dalam grup eksperimen yang ada dengan mengambil undian.

\section{Pengukuran}

Karena studi ini sebenarnya hanya bertujuan untuk mengulang dan mengembangkan studi Hobson (2008) dengan cara membuat intervensi membaca artikel edukasi menjadi lebih intensif, maka semua instrumen yang digunakan adalah sama dengan Hobson (2008). Instrumen tersebut telah diterjemahkan oleh penulis. Beberapa aspek instrumen telah disesuaikan agar layak digunakan pada sampel pekerja aktif. Berikut pemaparan instrumen-instrumen tersebut dan penyesuaiannya. Kami sudah berusaha meminta izin kepada penulis-penulis asli instrumen-instrumen di studi ini.

Sikap Terhadap Mencari Bantuan Psikologis Profesional. Instrumen ini pertama kali dibuat pada tahun 1970 dan direvisi pada tahun 1995 (ATSPPH-S; Fischer \& Farina, 1995; Fischer \& Turner, 1970; Hobson, 2008). Revisi pada tahun 1995 bernama Sikap Terhadap Mencari Bantuan Psikologis Profesional-versi singkat. Dalam versi yang disingkat ini, penulis skala memendekkan skala dengan merevisi aitem-aitem dari total 29 buah menjadi 10 buah (Hobson, 2008). Adanya kecenderungan positif terhadap layanan psikologis ditandai dengan nilai 10-25, sedangkan adanya kecenderungan yang negatif ditandai dengan nilai 26-40 (Hobson, 2008). Reliabilitas dan konsistensi skala dinyatakan cukup (Vogel, Wade \& Haake; 2006; Hobson, 2008). Terjemahan instrumen untuk studi ini ada di Appendiks C.

Daftar Komprehensif Intensi Untuk Mencari Konseling. Daftar ini dibuat oleh Cash, Begley, McCown, \& Weise (1975) yang bertujuan untuk mengukur kemungkinan peserta untuk menjalani konseling jika terkena masalah yang ada di daftar. Daftar ini terdiri dari 17 aitem dan dinilai dalam skala 1 (sangat tidak mungkin) hingga 4 (sangat mungkin). Jika partisipan lebih mungkin untuk mencari bantuan konseling, ini ditandai dengan range nilai 43-68. Sebaliknya ditandai dengan skor 17-42 (Hobson, 2008). Permasalahan yang ditampilkan termasuk masalah hubungan, depresi, masalah pribadi, dan masalah yang berhubungan dengan obat-obatan (Hobson, 2008). Semua subskala dalam daftar ini memiliki konsistensi internal yang baik (Hobson, 2008). Total skor dapat menandakan intensi mencari pelayanan psikologis jika dibutuhkan (Cepeda-Benito \& Short, 1998; Hobson, 2008). Perlu diketahui, untuk adaptasi skala ini ke kelompok yang sudah aktif bekerja, maka aitem 8, 9, 13, dan 15 diubah. Aitem 8

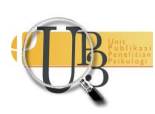


diubah dari kesulitan berkencan menjadi masalah cinta; aitem 9 diubah dari memilih mayor menjadi memilih pekerjaan; aitem 13 diubah dari ketegangan saat tes menjadi panik tugas kerja; aitem 15 diubah dari menunda tugas akademis menjadi menunda pekerjaan. Terjemahan instrumen untuk studi ini ada di Appendiks C.

Skala Stigma Pribadi Dalam Mencari Bantuan Psikolog. Vogel, Wade \& Haake (2006) membuat skala ini untuk mengukur stigma pribadi seseorang dalam mencari layanan kesehatan mental. Skala ini menggunakan skala likert untuk mengukur stigma pribadi seseorang dalam mencari layanan kesehatan mental dari 1 (sangat tidak setuju) sampai 5 (sangat setuju). Aitem di skala ini dirancang untuk mengevaluasi rasa kehilangan percaya diri dan harga diri seseorang ketika mereka memutuskan untuk mencari psikolog (Hobson, 2008). Sampel aitem misalnya "Jika saya pergi ke konselor untuk membantu masalah saya, saya akan merasa rendah diri." Partisipan dengan stigma pribadi yang lebih rendah mendapatkan kisaran skor dari 10 hingga 30 dan sebaliknya 31 hingga 50. Jika partisipan memiliki stigma pribadi yang lebih tinggi dan stigma negatif yang lebih tinggi terhadap layanan psikologi, maka skor mereka dalam skala ini akan lebih tinggi (Hobson, 2008). Terjemahan instrumen untuk studi ini ada di Appendiks C.

Skala Stigma Sosial Dalam Menerima Bantuan Psikolog.. Skala ini dibuat oleh Komiya, Good, dan Sherrod (2000) untuk menilai persepsi seseorang akan stigma sosial yang disematkan pada dirinya ketika menerima layanan psikologi (Hobson, 2008). Persepsi stigma sosial yang lebih rendah ditandai dengan skor 4 hingga 11 dan sebaliknya 12 hingga 20. Sebuah sampel dari aitem ini adalah "Jika seseorang telah berkonsultasi dengan psikolog, sangat disarankan agar hal ini disembunyikan dari orang di sekelilingnya." Skala ini memiliki konsistensi internal dan validitas konstruk" yang dapat diterima (Komiya, dkk., 2000; Hobson, 2008). Hubungan korelasi negatif antara SSRPH dan Sikap Terhadap Mencari Bantuan Layanan Psikologi Profesional menunjukkan validitas konstruk, dimana kecenderungan lebih positif seseorang terhadap mencari layanan psikologis berhubungan dengan persepsi sosial stigma yang lebih rendah (Komiya, dkk., 2000; Hobson, 2008). Terjemahan instrumen untuk studi ini ada di Appendiks C.

Artikel Edukasi Kesehatan Mental. Artikel ini mengikuti format tanya jawab seperti studi Hobson (2008). Dalam menyusun artikel ini, penulis telah mengkombinasikan informasi dari Hobson (2008), APA help centre (Change Your Mind About Mental Health; American Psychological Association, 2016), dan pengetahuan penulis sendiri. Artikel ini ada di dalam Appendiks B.

\section{Prosedur}

Partisipan studi diberi informasi mengenai studi oleh penulis sambil membaca form persetujuan dalam keadaan sadar (informed consent; lihat Appendiks A). Para partisipan yang telah menandatangani form persetujuan kemudian mengambil undian untuk dialokasikan secara acak ke grup eksperimen (intervensi atau kontrol). Dalam grup intervensi, pada hari pertama peserta mengisi survei pertama (pre-measurement) dan membaca artikel edukasi kesehatan mental. Pada hari kedua, ketiga, dan keempat; peserta intervensi hanya membaca artikel edukasi kesehatan mental. Pada hari kelima, peserta membaca artikel edukasi kesehatan mental dan kemudian mengisi survei terakhir (postmeasurement). Kami menyesuaikan frekuensi membaca artikel edukasi kesehatan mental sebanyak 5 kali seminggu karena merujuk pada studi Zajonc (1968, hal. 13) yang mendeskripsikan pemaparan sebanyak 5 kali sudah termasuk frekuensi yang cukup tinggi. Sedangkan grup kontrol hanya mengisi survei pada hari pertama dan kelima di tempat yang terpisah dengan peserta intervensi. Dalam studi ini, semua peserta mendapatkan jenis survei yang sama. Saat membaca dan mengisi survei, peserta

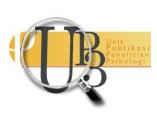


dalam pengawasan dan boleh bertanya pada pengawas jika ada hal yang tidak dimengerti. Peserta diberi kompensasi finansial atas waktu dan kehadiran mereka dalam studi tiap sesi.

\section{Analisis Data}

Data dianalisis dengan menggunakan IBM Statistical Program for Social Sciences (SPSS) versi 24. Karena keterbatasan jumlah sampel, maka variabel dependen yang dianalisa hanya dibatasi menjadi dua dari rencana semula empat variabel. Dua variabel terpenting yang dianalisa adalah stigma pribadi dan sosial.

Sesuai anjuran dari Hair, dkk. (2010), dalam studi multivariat, jika ada lima partisipan per variabel yang dianalisis (stigma pribadi dan sosial) adalah sudah cukup. Namun, studi ini tetap berpegang pada standar minimum 10 partisipan tiap variabel yang dianalisis. Ini konsisten dengan anjuran Sekaran (2003, hal. 295) yang mengatakan bahwa untuk studi dengan desain eksperimen dengan peserta kontrol, riset dapat sukses dengan hanya menggunakan sepuluh sampai dua puluh partisipan. Lebih lanjut, kami masih tetap pada pendirian kami untuk mengurangi jumlah variabel menjadi dua saja mengingat anjuran Sekaran (2003, hal. 295) juga, bahwa dalam riset multivariat, ukuran sampel harus beberapa kali lebih besar (jika bisa sepuluh kali) daripada jumlah variabel yang dianalisis (dependent variable) dalam studi (dua buah).

Dalam studi ini kami menggunakan independent groups $t$-test dan repeated measures $t$-test untuk menganalisa data kami. Lebih lanjut, dalam kasus data tidak berasal dari distribusi yang normal, kami akan menggunakan non-parametric test yang relevan. Dalam independent groups $t$-test, nilai rata-rata Skala Stigma Pribadi Dalam Mencari Bantuan Psikolog dan Skala Stigma Sosial dalam Menerima Bantuan Psikolog pada survei di hari terakhir studi milik grup intervensi dibandingkan dengan grup kontrol. Sedangkan pada repeated measures t-test, kami membandingkan penurunan nilai rata- rata Skala Stigma Pribadi Dalam Mencari Bantuan Psikolog dan Skala Stigma Sosial dalam Menerima Bantuan Psikolog pada survei hari pertama dan terakhir untuk grup intervensi dan kontrol secara terpisah. Kemudian, hasil penurunan nilai rata-rata kedua grup tersebut kami laporkan secara terpisah lengkap dengan dua buah signifikansinya di laporan ini untuk dibandingkan. Intinya, jika penurunan nilai rata-rata pada grup intervensi pada repeated measures t-test ini signifikan dan tidak signifikan pada grup kontrol, edukasi kesehatan mental memberikan kontribusi positif pada penurunan stigma pribadi dan sosial.

\section{HAS IL PENELITIAN}

Menggunakan independent groups t-test, kami menemukan bahwa peserta yang membaca artikel edukasi kesehatan mental secara intensif mendapatkan nilai rata-rata yang lebih rendah dalam variabel stigma pribadi $(M=25, S D=3.61)$ dibanding kontrol $(M=27, S D=4.53)$. Perbedaan rerata tidak signifikan $(\mathrm{t}(18)=-1.15, \mathrm{p}=.27, \mathrm{~g}=.48)$. Interval kepercayaan 95\% terendah adalah -5.95 dan tertinggi adalah 1.75. Kami menggunakan hedges g sebagai ukuran effect size karena keterbatasan sampel kami. Ini dikarenakan hedges $g$ adalah versi yang sama dengan Cohen's $d$, kecuali faktanya Cohen's $d$ belum mengkoreksi ukuran sampel yang kecil dan hedges $g$ sudah.

Lebih lanjut, menggunakan Mann-Whitney Test, kami menemukan bahwa peserta yang membaca artikel edukasi kesehatan mental secara intensif mendapatkan nilai rata-rata yang lebih rendah dalam variabel stigma sosial $(M=7.95)$ dibanding kontrol $(M=13.05)$. Perbedaan mean signifikan (Mann-Whitney $U=$ 24.5, $n_{1}=n_{2}=10, \mathrm{p}<.05$ ). Perkiraan effect size menurut Grissom \& Kim (2012) adalah .25. Effect size ini bekerja dengan cara memperkirakan kemungkinan skor yang didapat dari sebuah populasi lebih besar dari populasi lain yang diambil secara acak (Mark, 2012). Efek intervensi edukasi kesehatan mental

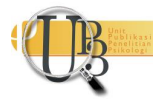


secara intensif adalah kecil pada stigma sosial, meskipun signifikan secara statistik. Kami tidak dapat menemukan interval kepercayaan untuk hasil Mann-Whitney Test.

$$
\hat{p}_{a . b}=\frac{U}{n_{a} n_{b}}
$$

Gambar 1. Rumus ukuran efek intervensi Menurut Grissom \& Kim (2012) untuk independent groups t-test

Data untuk stigma sosial dianalisa secara khusus menggunakan Mann-Whitney Test sebagai substitusi Independent groups t-test dikarenakan distribusi data tidak normal (Shapiro-Wilk=.879, p<.05); homoskedastisitas dan equality of variance terjaga. Lebih lanjut, dengan menggunakan repeated measures $t$-test; kami menemukan data-data dibawah ini.

Tabel 1. Repeated-Measures T-test Pada Variabel Studi Kecuali Stigma Sosial (Kontrol) (N=20)

\begin{tabular}{|c|c|c|c|c|c|}
\hline \multirow{2}{*}{ Variabel Pre-Post } & \multirow{2}{*}{$\begin{array}{c}\text { Perbedaan } \\
\text { Rerata }\end{array}$} & \multirow{2}{*}{ SD } & \multicolumn{2}{|c|}{ 95\% CI } & \multirow{2}{*}{ p-value } \\
\hline & & & Bawah & Atas & \\
\hline Stigma pribadi (Intervensi) & 3 & 6.5 & -1.65 & 7.65 & 0.18 \\
\hline Stigma pribadi (Kontrol) & 1.5 & 3.54 & -1.03 & 4.03 & 0.21 \\
\hline Stigma sosial (Intervensi) & 1.7 & 1.89 & 0.35 & 3.05 & 0.019 \\
\hline
\end{tabular}

Sedangkan berikut ini kami sajikan ukuran efek intervensi untuk variabel-variabel diatas. Perlu diketahui, bahwa dalam grup intervensi, edukasi kesehatan mental secara intensif memberikan efek yang besar untuk penurunan nilai rata-rata pada instrumen untuk mengukur stigma sosial ( $g=.81$ ). Penurunan nilai rata-rata tersebut juga signifikan $(\mathrm{p}<.05)$. Interval kepercayaan juga menunjukkan signifikansi tersebut dengan tidak adanya data yang menyentuh angka nol.

Tabel 2. Ukuran Efek Intervensi Repeated Measures T-test pada Variabel Studi Kecuali Stigma Sosial (Kontrol) (N=20)

\begin{tabular}{lc}
\multicolumn{1}{c}{ Variabel Pre-Post } & Effect Size (Hedges g) \\
\hline Stigma pribadi (Intervensi) & .41 \\
Stigma pribadi (Kontrol) & .38 \\
Stigma sosial (Intervensi) & .81 \\
\hline
\end{tabular}

Perbedaan nilai rata-rata sebelum dan sesudah untuk grup kontrol pada variabel stigma sosial dianalisa khusus menggunakan non-parametric test, karena distribusi datanya tidak normal (Pre-measurement; Shapiro-Wilk = .80, $p<.05$; Post-measurement; Shapiro-Wilk = .76, $p<.05$ ). Namun, distribusi data yang lainnya normal, termasuk untuk variabel stigma sosial dalam grup intervensi (Pre-measurement; Shapiro-Wilk = .88, $p<.05$; Post-measurement; Shapiro-Wilk $=.92, p<.05$ ).

Berdasarkan Wilcoxon Signed-Ranks Test, kami menemukan bahwa perbedaan rata-rata nilai survei hari pertama dan final studi pada grup kontrol pada variabel stigma sosial adalah tidak signifikan $(\mathrm{Z}=1.48$, p=.14). Effect size menurut Grissom \& Kim (2012) adalah .70 (efek moderat). Rumus untuk menghitung efek intervensi tersebut adalah:

$$
P S_{d e p}=\frac{n_{+}}{N}
$$

Gambar 2. Rumus Ukuran Efek Intervensi untuk Repeated-Measures T-Test (Grissom \& Kim, 2012)

Jadi ketika kita membandingkan penurunan nilai stigma sosial pada pengukuran sebelum dan sesudah intervensi pada grup intervensi dan kontrol pada variabel stigma sosial, kami menemukan bahwa penurunan nilai rata-rata pada grup intervensi adalah signifikan dengan merujuk pada nilai $\mathrm{p}$ dan

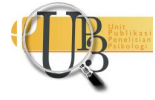


interval kepercayaan 95\% dengan ukuran efek intervensi yang besar. Sedangkan penurunan pada grup kontrol pada variabel yang sama adalah tidak signifikan dengan merujuk pada nilai $\mathrm{p}$ dan effect size adalah moderat. Kami tidak dapat menemukan ukuran interval kepercayaan dari Wilcoxon Signed-Ranks test.

\section{I S K U S I}

Dari analisis hasil studi kami, dapat disimpulkan bahwa menurut independent groups $t$-test, penurunan stigma pribadi setelah edukasi kesehatan mental secara intensif dengan cara membaca artikel intervensi pada peserta studi kami adalah tidak signifikan. Maka kami tidak menolak $\mathrm{H}_{0}$ bahwa tidak ada perbedaan antara rata-rata grup intervensi dan kontrol pada variabel stigma pribadi $\left(\mu_{\mathrm{K}}=\mu_{\mathrm{I}}\right)$.

Lebih lanjut, berdasarkan hasil Mann-Whitney Test, penurunan stigma sosial setelah edukasi kesehatan mental secara intensif dengan cara membaca artikel intervensi pada peserta studi kami adalah signifikan dengan effect size kecil. Maka kami menolak $\mathrm{H}_{0}$ bahwa tidak ada perbedaan antara rata-rata grup intervensi dan kontrol pada variabel stigma sosial $\left(\mu_{\mathrm{K}}=\mu_{\mathrm{I}}\right)$.

Selanjutnya, dalam repeated measures $t$-test, kami tidak menolak $\mathrm{H}_{0}$ bahwa tidak ada perbedaan signifikan antara nilai rata-rata grup intervensi, sebelum dan sesudah intervensi secara intensif pada variabel stigma pribadi $\left(\mu_{D}=0\right)$. Lebih lanjut, dalam repeated measures $t$-test, kami juga tidak menolak $\mathrm{H}_{0}$ bahwa tidak ada perbedaan signifikan antara nilai rata-rata grup kontrol, saat sesi pertama dan terakhir studi pada variabel stigma pribadi $\left(\mu_{D}=0\right)$. Ini dikarenakan perbedaan rerata kedua grup tersebut tidak signifikan.

Lebih lanjut, dalam repeated measures t-test, kami menolak $\mathrm{H}_{0}$ bahwa tidak ada perbedaan signifikan antara nilai rata-rata grup intervensi, sebelum dan sesudah intervensi secara intensif pada variabel stigma sosial $\left(\mu_{D}=0\right)$. Ini dikarenakan perbedaan mean sebelum dan sesudah intervensi adalah signifikan ( $\mathrm{p}<.05)$, juga interval kepercayaan yang tidak menyentuh angka nol. Ukuran efek intervensi juga menunjukkan bahwa efek membaca artikel edukasi kesehatan mental secara intensif adalah besar terhadap penurunan stigma sosial partisipan terhadap penderita gangguan jiwa dan layanannya.

Terakhir, dalam Wilcoxon Signed-Ranks Test, kami menemukan $\mathrm{H}_{0}$ bahwa tidak ada perbedaan signifikan antara nilai rata-rata grup kontrol, saat sesi awal dan akhir studi pada variabel stigma sosial $\left(\mu_{D}=0\right)$ dapat diterima $(\mathrm{p}<.14)$. Namun, perbedaan rerata menunjukkan effect size yang moderat dalam keadaan tidak ada intervensi apapun. Effect size moderat dalam keadaan tidak ada intervensi dan besar dalam keadaan ada intervensi pada variabel stigma sosial menunjukkan bahwa efek bersih intervensi adalah kecil.

Maka, berdasarkan hasil independent groups t-test, intervensi membaca artikel edukasi kesehatan mental secara intensif dapat menurunkan stigma sosial secara signifikan, namun efektifitasnya kecil. Sedangkan, intervensi membaca tidak dapat menurunkan stigma pribadi secara signifikan. Lebih lanjut, menurut repeated measures t-test membaca artikel edukasi kesehatan mental secara intensif dapat menurunkan stigma sosial secara signifikan pada grup intervensi dengan efek yang besar. Namun, pada grup kontrol yang tidak memiliki intervensi apapun efek penurunan nilai rata-rata pada variabel stigma sosial adalah moderat. Terakhir, menurut repeated-measures $t$-test, penurunan level stigma pribadi pada grup kontrol dan intervensi adalah tidak signifikan. Namun, penurunan nilai rata-rata grup intervensi adalah dua kali lipat dibandingkan grup kontrol dalam variabel stigma pribadi dan nilai p berbeda tiga poin.

Ini membawa kita kepada kesimpulan bahwa intervensi membaca artikel edukasi kesehatan mental secara intensif kurang efektif dalam mengurangi stigma pribadi individu secara signifikan pada layanan kesehatan mental dan penggunanya. Namun, membaca artikel edukasi kesehatan mental secara intensif dapat menurunkan persepsi stigma sosial terhadap penderita gangguan jiwa dan layanannya secara INSAN Jurnal Psikologi dan Kesehatan Mental 2017, Vol. 2(1), 1-21

doi: 10.20473/jpkm.v2i12017.1-21

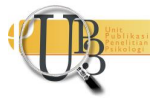


signifikan. Tetapi, meskipun penurunan stigma sosial karena membaca artikel edukasi kesehatan mental secara intensif signifikan secara statistik, effect size dalam kasus ini secara berturut-turut dari independent groups dan repeated measures t-test adalah kecil.

Efek edukasi kesehatan mental secara intensif yang tidak signifikan terhadap penurunan stigma pribadi dan signifikan terhadap penurunan stigma sosial dengan efek kecil konsisten dengan Corrigan, dkk. (2001). Misalnya, Corrigan, dkk. (2001) menemukan bahwa edukasi kesehatan mental cenderung lebih efektif menurunkan atribusi stabilitas dan kurang efektif menurunkan atribusi kontrolabilitas. Yakni, edukasi kesehatan mental dapat meyakinkan orang di sekitar penderita bahwa layanan kesehatan mental seperti konseling dapat memberi efek yang menguntungkan untuk penderita (atribusi stabilitas) (Corrigan, dkk., 2001, hal. 193).

Sedangkan, penolakan masyarakat lebih berhubungan dengan atribusi kontrolabilitas (Weisman, dkk., 1993; Crandall \& Moriarty, 1995; Hooley \& Licht, 1997; Corrigan, dkk., 2001). Menurut definisi, stigma terhadap penderita gangguan jiwa juga lebih berhubungan dengan atribusi kontrolabilitas. Ini dikarenakan karena stigma pribadi adalah internalisasi stigma sosial dan ditandai salah satunya dengan persepsi bahwa individu itu sendiri tidak kompeten dalam hidupnya karena kondisi jiwanya (Hobson, 2008). Maka dari itu, tidak mengherankan bahwa efek intervensi edukasi kesehatan mental secara intensif terhadap partisipan memiliki efek yang tidak signifikan dan kecil terhadap stigma pribadi dan sosial pada penderita gangguan jiwa dan layanannya. Peran lebih besar atribusi kontrolabilitas terhadap penolakan masyarakat juga cukup beralasan. Ini dikarenakan reaksi manusia yang lebih mungkin dilakukan terhadap bahaya yang dirasa datang dari perilaku orang yang terkena gangguan jiwa adalah takut (Johnson-Dalzine, dkk., 1996; Corrigan, 2000). Reaksi ini jauh lebih dominan dari reaksi kemarahan yang berujung pada reaksi punitif, misalnya perawatan psikologis terhadap penderita gangguan jiwa (Corrigan, 2000).

Namun, kami juga merasa studi kami mungkin belum mampu menggambarkan efek edukasi kesehatan mental secara intensif dengan jelas. Ini dikarenakan sampel dalam studi kami meskipun cukup untuk studi dengan desain eksperimen, ukuran sampel yang lebih besar mungkin dapat menangkap efek intervensi yang saat ini kami belum dapatkan. Misalnya, dalam studi Hobson (2008) didapatkan bahwa intervensi membaca secara singkat artikel edukasi kesehatan mental yang hampir sama dengan studi ini dapat menurunkan stigma pribadi dan sosial secara signifikan menurut statistik. Misalnya, partisipan yang membaca artikel edukasi kesehatan mental (grup eksperimen) mempunyai skor rerata yang lebih rendah dalam skala Self Stigma of Seeking Help Scale $(\mathrm{M}=23.30, \mathrm{SD}=6.56)$ dibanding kontrol $(\mathrm{M}=25.88$, $\mathrm{SD}=6.87, t(194)=2.688, \mathrm{p}<.008)$. Lebih lanjut, partisipan yang membaca artikel edukasi kesehatan mental (grup eksperimen) mempunyai skor rerata yang lebih rendah dalam skala Social Stigma for Receiving Psychological Help $(M=10.07, \mathrm{SD}=3.16)$ dibanding kontrol $(M=12.71, \mathrm{SD}=3.15, t(194)=5.846$, $\mathrm{p}<.001$ ) (Hobson, 2008, hal. 28).

Lebih lanjut, menurut Zajonc (1968), ketika partisipan dipaparkan ke sebuah konsep secara intensif, maka secara afektif, asosiasi antara emosi dengan konsep tersebut akan lebih positif. Namun, kami tidak menemukan penurunan yang signifikan pada stigma pribadi setelah konsep kesehatan mental kami paparkan secara intensif kepada partisipan melaluli bacaan artikel psikoedukasi. Maka, kami menduga bahwa perubahan dari sisi afektif terhadap konsep layanan kesehatan mental setelah konsep tersebut kami paparkan secara intensif tidak cukup untuk mengubah persepsi partisipan terhadap stigma pribadi yang ditimbulkan dari penggunaan layanan kesehatan mental. Kemungkinan lainnya adalah pemaparan kami belum cukup intensif untuk mengubah persepsi afektif partisipan kami terhadap konsep kesehatan mental, sehingga tidak ada penurunan yang signifikan terhadap persepsi stigma pribadi tersebut. Ini dapat dikarenakan persepsi negatif masyarakat terhadap masalah kesehatan jiwa sudah melekat sangat kuat sehingga usaha untuk mengubah persepsi tersebut adalah sulit. Asosiasi

INSAN Jurnal Psikologi dan Kesehatan Mental

2017, Vol. 2(1), 1-21

doi: 10.20473/jpkm.v2i12017.1-21

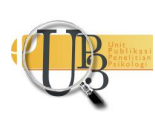


yang kuat antara kedua hal tersebut dapat terlihat karena adanya asosiasi antara perilaku "aneh" dari penderita gangguan jiwa yang sudah diasosiasikan dengan ancaman dan rasa takut (Johnson-Dalzine, dkk., 1996; Corrigan, 2000).

Sedangkan studi kami yang telah menggunakan metode membaca artikel edukasi kesehatan mental sebagai intervensi secara intensif hanya menemukan hasil signifikan menurut statistik pada penurunan stigma sosial terhadap pengguna layanan kesehatan mental dan layanannya. Maka, kami menganjurkan agar studi yang memiliki sampel yang lebih besar meneliti lebih lanjut efek membaca artikel edukasi kesehatan mental secara intensif terhadap stigma sosial dan pribadi pada penderita gangguan jiwa dan layanannya untuk merekonsiliasi perbedaan temuan antara studi Hobson (2008) dan studi ini dalam konteks sampel Indonesia.

\section{S I M P U L A N}

Lebih lanjut, kami juga menganjurkan agar lebih banyak riset mengurangi stigma difokuskan kepada kontak sosial antara masyarakat dan penderita gangguan jiwa. Misalnya, ini dapat dilakukan dengan kontak singkat secara langsung antara masyarakat dan penderita gangguan jiwa dengan cara si penderita menceritakan gangguan jiwanya dan penyembuhan yang dia jalani (Corrigan, dkk., 2001). Riset ke kontak sosial antara masyarakat dan penderita gangguan jiwa sangat menguntungkan karena ditemukan lebih efektif menurunkan stigma terhadap gangguan jiwa daripada program edukasi. Ini dikarenakan, dalam kontak sosial, orang lain dapat menerima lebih banyak informasi mengenai kehidupan si penderita gangguan jiwa, sehingga dapat memberi atribusi yang lebih tepat (Corrigan, dkk., 2001, hal. 193). Ini dikarenakan pemaparan secara sosial ke grup lainnya yang dipersepsikan negatif dapat memperbaiki kecenderungan terhadap grup itu. Misalnya, dengan melakukan pemaparan tersebut, kita akan belajar belajar cara pandang (perspective taking) grup itu dengan dimediasi oleh empati dan atribusi sosial; akhirnya mengubah attitude kita terhadap grup itu menjadi lebih baik (Vescio, dkk., 2003).

Namun, studi ini telah menunjukkan bahwa stigma sosial terhadap penderita gangguan jiwa dapat diturunkan secara signifikan menurut statistik melalui tindakan membaca artikel yang berisi edukasi kesehatan mental secara intensif. Lebih lanjut, studi ini telah berusaha mempelopori usaha meneliti efek pemaparan secara intensif pada konsep kesehatan mental terhadap penurunan level stigma pribadi dan sosial pada pengguna layanan kesehatan mental dalam konteks sampel Indonesia. Selain itu, intervensi melalui edukasi kepada publik juga menguntungkan karena menelan biaya yang murah dan jangkauannya pun bisa luas (Corrigan, Kerr \& Knudsen, 2005, hal. 184). Misalnya, edukasi kesehatan mental dapat dimuat di media massa seperti televisi dan koran dalam acara-acara dan artikel khusus dan dapat menjangkau cakupan yang luas. Maka dari itu, edukasi kesehatan mental dapat menjadi cara yang baik bagi program Indonesia Bebas Pasung 2019 untuk mengurangi stigma pribadi dan sosial bagi penderita gangguan jiwa dan layanannya di Indonesia. Ini dikarenakan biaya edukasi yang murah dan jangkauannya dapat luas hingga ke seluruh Nusantara. Dengan demikian, penelitian ini telah mendukung program Indonesia Bebas Pasung 2019 dengan cara meneliti metode yang tepat untuk menurunkan stigma terhadap penderita gangguan jiwa dan layanan kesehatan mental (Lestari \& Wardhani, 2014, hal. 160).

\section{PUSTAKA ACUAN}

American Psychological Association. (2016). Change your mind about mental health. Diakses dari http://www.apa.org/helpcenter/change.aspx.

Badan Penelitian dan Pengembangan Kesehatan. (2008). Laporan Nasional Riset Kesehatan Dasar

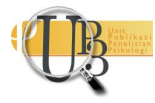


Tahun 2007, Jakarta: Badan Penelitian dan Pengembangan Kesehatan Kementerian Kesehatan RI.

Cash, T.F., Begley, P.J., McCown, D.A., \& Weise, B.C. (1975). When counselors are heard but not seen: Initial impact of physical attractiveness. Journal of Counseling Psychology, 22, 273-279.

Cepeda-Benito, A., \& Short, P. (1998). Self-concealment, avoidance of psychological services, and perceived likelihood of seeking professional help. Journal of Counseling Psychology, 45, 58-64.

Corrigan, P. W. (2000). Mental health stigma as social attribution: Implications for research methods and attitude change. Clinical Psychological Science Practice, 7, 48-67.

Corrigan, P. W., River, P. L., Lundin, R. K., Penn, D. L., Uphoff-Wasowski, K., Campion, J., Mathisen, J., Gagnon, C., Bergman, M., Goldstein, H., Kubiak, M. A. (2001). Three Strategies for Changing Attributions about Severe Mental Illness. Schizophrenia Bulletin, 27(2), 187-195.

Corrigan, P. W. (2004). How stigma interferes with mental health care. American Psychologist, 59(7), 614-625. doi:10.1037/0003-066X.59.7.614

Corrigan, P. W., Kerr, A., Knudsen, L. (2005). The stigma of mental illness: Explanatory models and methods for change. Applied and Preventive Psychology, 11, 79-190.

Corrigan, P. W., River, L. P., Lundin, R. K., Wasowski, K. U., Campion, J., Mathisen, J., Goldstein, H., Bergman, M., Gagnon, C., \& Kubiak, M. A. (dalam penerbitan). Stigmatizing attributions about mental illness. Journal of Community Psychology.

Crandall, C.S., and Moriarty, D. (1995). Physical illness stigma and social rejection. British Journal of Social Psychology, 34:67-83.

Eysenck, M. W. (2009). Fundamentals of Psychology. New York: Psychology Press.

Fischer, E.H., \& Farina, A. (1995). Attitudes toward seeking professional psychological help: A shortened form and considerations for research. Journal of College Student Development, 36, 368-373.

Fischer, E.H., \& Turner, J.L. (1970). Development and research utility of an attitude scale. Journal of Consulting and Clinical Psychology, 35, 79-90.

Goffman, E. (2009). Stigma: Notes on the management of spoiled identity. New York: Simon and Schuster.

Grissom, R. J., \& Kim, J. J. (2012). Effect sizes for research: Univariate and multivariate applications. ( $2^{\text {nd }}$ ed.). New York, NY: Taylor \& Francis.

Hair, J. F., Black, W. C., Babin, B. J., \& Anderson, R. E. (2010). Multivariate Data Analysis: Pearson Prentice Hall.

Hobson, H. L. (2008). The effects of mental health education on reducing stigma and increasing positive attitudes toward seeking therapy. (Masters of Arts In Psychology: Counseling thesis, Humboldt State University, 2008). Humboldt Digital Scholar, HSU Master's Theses \& Projects [1422].

Hooley, J.M., and Licht, D.M. (1997) Expressed emotion and causal attributions in the spouses of depressed patients. Journal of Abnormal Psychology, 106:298-306, 1997.

Johnson-Dalzine, P., Dalzine, L., \& Martin-Stanley, C. (1996). Fear of criminal violence and the African

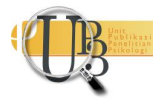


American elderly: Assessment of a crime prevention strategy. Journal of Negro Education, 65, 462469.

Keane, M. (1990). Contemporary beliefs about mental illness among medical students: Implications for education and practice. Academic Psychiatry, 14, 172-177.

Komiya, N., Good, G.E., Sherrod, N.B. (2000). Emotional Openness as a Predictor of College Students' Attitudes towards Seeking Psychological Help. Journal of Counseling Psychology, 47(1), 138-143.

Lin, Z. (1993). An exploratory study of the social judgements of Chinese college students from the perspectives of attributional theory. Acta Psychologica Sinica, 25, 155-163.

Lestari, W., Wardhani., Y. F. (2014). Stigma dan Penanganan Penderita Gangguan Jiwa Berat yang Dipasung. Buletin Penelitian Sistem Kesehatan, 17(2), 157-166.

Lyons, M. \& Ziviani, J. (1995). Stereotypes, stigma and mental illness: Learning from fieldwork experiences. American Journal of Occupational Therapy, 49, 1002-1008.

Mark, J. (2012). Nonparametric Effect Size Estimators.

Mirabi, M., Weinman, M. L., Magnetti, S. M., \& Keppler, K. N. (1985). Professional attitudes toward the chronic mentally ill. Hospital and Community Psychology, 36, 404-405.

Page, S. (1980). Social responsiveness toward mental patients: The general public and others. Canadian Journal of Psychiatry, 25, 242-246.

Scott, D. J., \& Philip, A. E. (1985). Attitudes of psychiatric nurses to treatment and patients. British Journal of Medical Psychology, 58, 169-173.

Sekaran, U. (2003). Research Methods for Business (4th ed.). New York John Wiley \& Sons, Inc.

Suryani (2013). Dr. Suryani, SKp., MHSc, “Setiap Tahun, Penderita Gangguan Jiwa di Indonesia Terus Meningkat.” Diakses dari http://www.unpad.ac.id/profil/dr-suryani-skp-mhsc-setiap-tahunpenderita-gangguan-jiwa-di-indonesia-terus-meningkat/

Vescio, T. K., Sechrist, G. B., \& Paolucci, M. P. (2003). Perspective taking and prejudice reduction: the mediational role of empathy arousal and situational attributions. European Journal of Social Psychology, 33, 455-472. doi:10.1002/ejsp.163.

Vogel, D.L, Wade, N.G., Haake, S. (2006). Measuring the Self-Stigma Associated with Seeking Psychological Help. Journal of Counseling Psychology, 53(3), 325-337.

Weiner, B. (1993). On sin versus sickness: A theory of perceived responsibility and social motivation. American Psychologist, 48, 957-965.

Weiner, B. (1995). Judgements of responsibility: A foundation for a theory of social conduct. New York: Guilford Press.

Weisman, A., Lopez, S.R., Karno, M., \& Jenkins, J. (1993). An attributional analysis of expressed emotion in Mexican-American families with schizophrenia. Journal of Abnormal Psychology, 102:601-606.

Zajonc, R. B. (1968). Attitudinal effects of mere exposure. Journal of Personality and Social Psychology, 9(2), 1-27. 